\title{
Youth activism through Social media in Assam: An Exploratory Study
}

\author{
MANOJ DEORI and SUNIL K. BEHERA
}

\begin{abstract}
The paper is an attempt to study the online participation behavior of youth in Assam in organizing social and political protests through Social media. During several protest demonstrations and rallies which took place in the middle of the year, 2012; there has been a series of cyber activism that took place prior to the street demonstrations and rallies. The paper attempts to justify the fact that, the street demonstrations and rallies which took place during that particular period, gained its momentum largely through Social Media. Therefore the period can be regarded as the beginning of cyber activism in Assam, since such online activities in publicizing and organizing any collective action in the physical world with regards to activism was not seen in the past. Based on the data collected through onsite surveys, such online communities have considerably given rise to new forms of collective action such as on/offline social and political protest in Assam through social media by publicizing and organizing people where the predominance of the youths is distinctly visible. It is seen that, there has been an increasing number of cyber activism among the online 'Assamese' youth communities which has apparently given raise to cyber-civil societies in urban areas. The predominance of youth in such protests is visible, since the use of social media has become a popular culture among the youth. About $17 \%$ of the Indian populations are between 15 and 24 and they are experiencing the changes brought by the New Media technology. In examining the practices on social media, authors focus primarily on "Facebook", which is the most popular social networking site in social media. Series of protest took place in the months of July, August and September, 2012 against unethical media practices; particularly the television media in Assam. Eventually protests against the insecurity of the women in Guwahati, the capital city of Assam and protest against illegal Bangladeshi immigrants in Assam were also demonstrated on the streets of Assam which gathered huge civic support. Few youth groups from Assam were also established who organized themselves through social networking sites to raise street demonstrations, along with certain other political parties, NGOs and offline civil society groups. The paper mainly studies the participation of youth in such protests and reflects on the case studies which can be regarded as the beginning of youth cyber activism that apparently gained momentum through social media in Assam.
\end{abstract}

Keywords: Social Media, Social Network and Youth activism

Penetration of internet and the wide use of mobile phones and its application technologies have popularized the use of social media among the masses, especially the youth (Boyed, 2007). It has become a big platform for people to create content, share it, bookmark it and network at a remarkable rate. Strangers use social networking sites to communicate and share their opinion with each other in this participatory media on the basis of shared interests, political views, or activities. (Boyed and Ellision, 2007). Social media is very quickly changing the public discourse and setting trends among the masses. Various agendas have been raised in such discourses on different issues that range from the environment and politics to technology and the entertainment industry. The 
potential of social media in mobilizing public opinion and organizing protests on issues, say, social, political and environmental etc. cannot be underestimated considering their role in the popular uprising across the Middle East and North Africa (Axford, 2011) against the authoritarian regimes.

New media technologies have been constituted of individual, social, and political changes in China-some quite progressive, and some not (Wallis, 2011). India is also not left untouched by the changes brought by the Social media revolution. About $17 \%$ of the Indian populations are between 15 and 24 and they are experiencing the changes brought by the New Media technology (Schwittay, 2011). The recent trends in youth activism in Assam have undergone a series of change, Cyber civil society groups were created in social media which gained tremendous response from the youth. Issues pertaining to the social, political and environmental importance were discussed and in some instances these virtual groups have also stepped outside the cyberspace to participate in the street demonstrations and organized social events in the real world. The real is approached through, grasped and understood via the virtual and the virtual is constituted by the real (Nayar, 2008). The information and communication technology has largely influenced such participations by increasing the speed, reach and effectiveness of the communication. These multiple networks of connected citizens and activists transform the so-called 'dumb mobs' of totalitarian and polyarchical states into 'smart mobs' of socially active personages (Kahn and Kellner, 2004).

\section{Cyber activism in Assam}

On July $9^{\text {th }} 2012$ at around 9-10 P.M, a girl from Guwahati was molested by a group of men when she came out of a bar in busy GS Road in Guwahati, Assam. The Incident was captured on camera by a reporter of a local news channel, based in Guwahati. The video went viral on internet and there was a state and nationwide outrage. The editor in chief of the local news channel uploaded the video of the molestation and faced wide criticism for uploading it in 'You Tube' (video sharing site). He was also criticized as to why reporters of the channel continued shooting that video instead of helping the girl. He later defended himself in social media and in various television and News paper interviews by saying that the reporters recorded it for evidence of the police.

There was a series of protest on $14^{\text {th }}$ and $15^{\text {th }}$ July, 2012 in which many NGOs and civil society groups participated in these protests. Meanwhile youth from Assam were also campaigning on the social networking site, 'Facebook', against the incident and such online communities organized themselves in the social network site and mobilized themselves to demonstrated protest on the streets on $15^{\text {th }}$ July 2012. The youth under the aegis of 'Music and Peace' organization and 'Facebook' community gathered at the incident site on GS Road and took out rally. A black dress code was selected for the occasion. They shouted slogans of "Soch Badlo Kapde nahi" (Change mindset not dress) and "respect Woman". Their march started from the very point where the shameful incident with the girl had taken place on the night of $9^{\text {th }}$ July, 2012 on GS road of Guwahati, Assam. A particular group of people through various media opined that, the girl invited the atrocity to herself by wearing indecent dress which instigated the crime. Such Comments were strongly offended among the 'Facebook' community by the youths and with their Slogan "Soch Badlo Kapde Nahi" (Change mindset not dress) the protest came to the streets.

This incident can be perhaps regarded as the beginning of Cyber activism by the youths in Assam. The protest demonstrations on the streets got a huge offline response as well, while the online youth groups stepped out of the cyber world 
to physically participate in the same. The news was covered by the national media and renowned Journalists and personalities from India as well as abroad commented in social media on the issue. The then Chief Minister of Assam, Mr. Tarun Gogoi ordered probe and arrest of the culprits. The editor-in-chief of the concerned local news channel was also widely criticized in social media and resigned on $17^{\text {th }}$ July, 2012. The reporter of the News Channel who was alleged of instigating the mob in molesting the girl was also taken under police custody for further investigations. A big question was asked to the media, especially television news channels about its ethicality which have been to a great extend blinded by the TRP (Television rating points). The television news media faced a grim criticism from the people for moral policing without possessing adequate values for it. In the meantime the photographs of the culprits were widely circulated in social media for identification and within a short period of time all the culprits were arrested except the main accused. By then the 'Facebook' communities have publicized his identification by uploading photographs and videos in social media making his hideout more difficult to remain untraced. Eventually the main accused was also arrested on $24^{\text {th }}$ of July, 2012 from Varanasi, Uttar Pradesh in India.

After the episode of the GS road incident such online young communities also organized protest demanding justice for Pritam Bhattacharjee, a young student from Guwahati University who was travelling towards Delhi to pursue his doctorate and was killed on a train on $9^{\text {th }}$ July 2012 by some miscreants in Bihar, who tried to loot him. His body was recovered near a railway station in Bhagalpur district of Bihar on July $15^{\text {th }} 2012$.

The online communities were mobilized in Facebook and eventually a protest march was organized on the same month of July $22^{\text {nd }}, 2012$ in Guwahati demanding the arrest of the culprits. A good number of youth participation was seen in the demonstration. The news was also carried by national media and in due course the culprits were arrested.

Besides these issues, one of the growing issues in social media among the people of Assam has been the illegal immigration of people from Bangladesh, a bordering country of India. Several Facebook communities have been formed in which members have actively participated in cyber activism against such immigrations. Some of the communities have crossed 3,000 members and the number is still increasing every day.

"stop and eradicate illegal bangladeshi im migration", is a popular group in Facebook among the Assamese communities. The community uses this platform to share news articles from the news papers in Assam regarding such immigration and share their comment on the political as well as the social repercussions. They also share their views and comments with opinions of each other. And it is seen that there is a strong grievance among the people on such illegal immigration from Bangladesh. Consequently such anger and grievances were also seen on the streets of Guwahati and several parts of Assam during many protest rallies under the aegis of several students' body organizations. The demonstrations were joined by thousands of young students from schools, colleges and the universities who are perhaps the users of social media.

On $9^{\text {th }}$ August, 2012 NESO (North East Students Organisation), AASU (All Assam Students' Union) and many other Student bodies jointly organized a protest rally in Guwahati who demanded the update of the NRC (National Register of Citizen) and quick implementation of the core principles enshrined in the Assam Accord (1985), Which was a Memorandum of Settlement (MoS) signed between representatives of the Government of India and the leaders of the Assam Movement in New Delhi on 15 August 1985. The accord brought an end to the Assam Agitation and 
paved the way for the leaders of the agitation to form a political party and form a government in the state of Assam soon after.

Consequently on $31^{\text {st }}$ August, 2012 All Assam Students Union (AASU) took out protest rallies in the Sivsagar district of Assam against illegal Bangladeshi migrants in the state. $6^{\text {th }}$ September, 2012 NESO and AASU organized protest rally in Guwahati in which thousands of people took part. On $15^{\text {th }}$ September, 2012 Bodo Students Union (ABSU) organized demonstration in Kokrajhar town in Assam which was supported by 26 other organizations and school and college students. On $21^{\text {st }}$ September, 2012 the All Assam Student's Union (AASU) along with 25 other organizations representing various ethnic groups of the state took out protest marches across Assam, seeking urgent measures from the state government to detect and deport illegal Bagladeshis settled in the state. Students and youth activists joined hands with locals in Nogaon, Dhemaji, Golaghat and Bongaigaon districts and also in Mangaldoi and on Berpeta Road to intensify the ongoing stir against illegal migrants. On $24^{\text {th }}$ September, 2012, AASU (All Assam Students' Union) from the Guwahati University wing organized protest rally which was joined by thousands of young students in Guwahati.

\section{Methodology}

The survey method of research is followed in this descriptive study to help gather varied views of participants. Both qualitative and quantitative methods are employed to study the environment related to cyber activism. Web content analysis along with the online electronic survey method was employed to carry out the study to make the study practical or financially feasible to access the population (Andrews et a., 2003). Online request were sent to the participants among the youths of Assam to answer the questionnaire. Computer assisted data analysis was carried to analyze the data collected through online survey.

\section{Sample selection}

Guwahati, being the capital city of Assam is a major center for administrative and political activities in Assam. Guwahati ranks very high in terms of industrial growth, education and public participation. The city is an important regional hub for transportation. Guwahati is one of the most rapidly growing cities in India. According to the census 2011, Guwahati city has population of 963,429 ; its urban / metropolitan population is 968,549 of which 505,542 are males and 463,007 are females. Average literacy rate of Guwahati city is 91.11 percent of which male and female literacy was 92.89 and 89.16 percent. It is assumed that the study of youth cyber activism in Guwahati would be representative of the same in other parts of the state.

\section{Sample Size}

The determination of sample size is done by applying Krejcie and Morgan's (1970) findings. The sample size has been given as 384 for a population of $1,000,000$. The population of Guwahati (kamrup Metro) is 9, 68,549 (Census, 2011). Based on this, the sample size adequate for this study is 384 . However for ensuring better statistical analysis, a total of 450 samples have been collected. 


\section{FINDINGS}

\section{The most popular Social Networking site}

It was found that Facebook is the most popular among other social networking sites between the youths of Assam. $87.67 \%$ of all the total respondents use Facebook for social networking.

Figure (1). Most popular social networking site among the respondents

\begin{tabular}{|l|l|l|l|l|}
\hline \multicolumn{1}{|c|}{$\begin{array}{l}\text { Total (\% \& freq } \\
\text { col), Twitter, 9.59\% }\end{array}$} & & \\
\hline & & & \\
\hline & $87.67 \%$ \\
\hline $\begin{array}{c}\text { व Total (\% \& freq } \\
\text { col), Orkut, 1.37\% }\end{array}$ & & & & \\
\hline $\begin{array}{c}\text { Total (\% \& freq } \\
\text { col), Myspace, 0.00\% }\end{array}$ & & & \\
\hline $\begin{array}{c}\text { Total (\% \& freq } \\
\text { col), Other, please } \\
\text { specify, 1.37\% }\end{array}$ & & & & \\
\hline
\end{tabular}

\section{Organizing events at Facebook}

$19.18 \%$ of the total participants always organize events at Facebook and meet themselves at real and $52 \%$ organize events sometimes, whereas $31 \%$ of all the participants never organize events at Facebook and meet in real.

Figure (2). Perception of the respondents in organizing events at Facebook prior to meeting in real

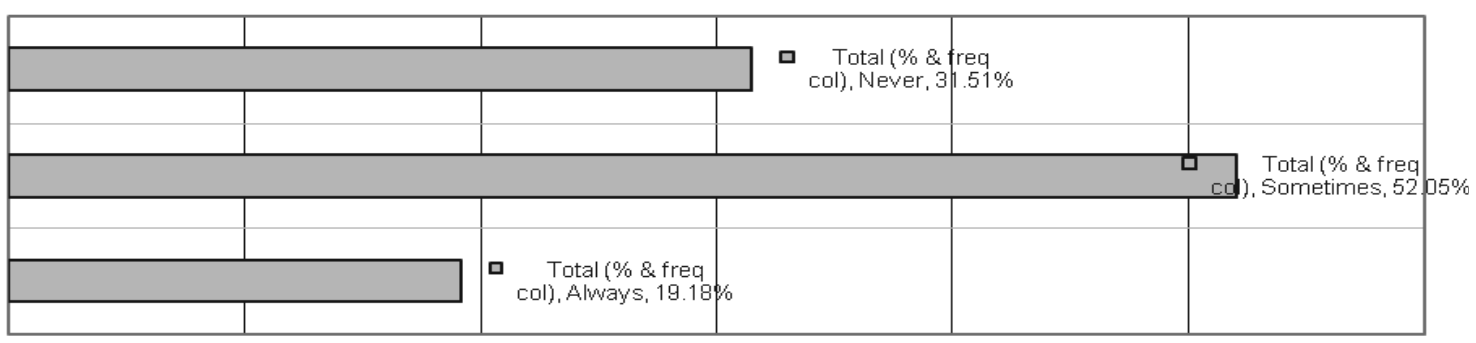

\section{Participation in discussions}

$35.62 \%$ of the total respondents always participate in discussions at Facebook Communities regarding various issues rather than personal issues, whereas $56 \%$ participate sometimes and $8.22 \%$ of all the total respondents never participate in such discussions. 
Figure (3). Perception of the respondents regarding their participation in discussions related to issues rather than personal

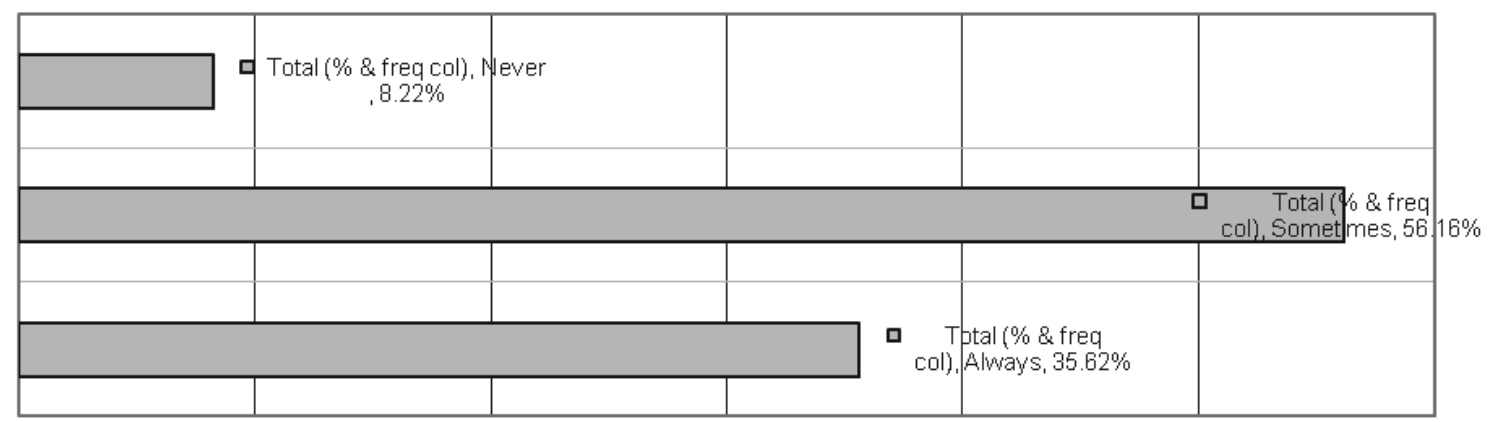

\section{Popular discussions in Facebook}

$86.30 \%$ of all the participants take part in the discussions in Facebook related to social issues, $43.84 \%$ take part in discussions related to political issues and $36.99 \%$ take part discussions related to environmental issues and $26.03 \%$ in personal issues, whereas $2.74 \%$ take part in discussions in other issues.

Figure (4). Perception of the respondents relating to issues in which they participate on discussions in Facebook

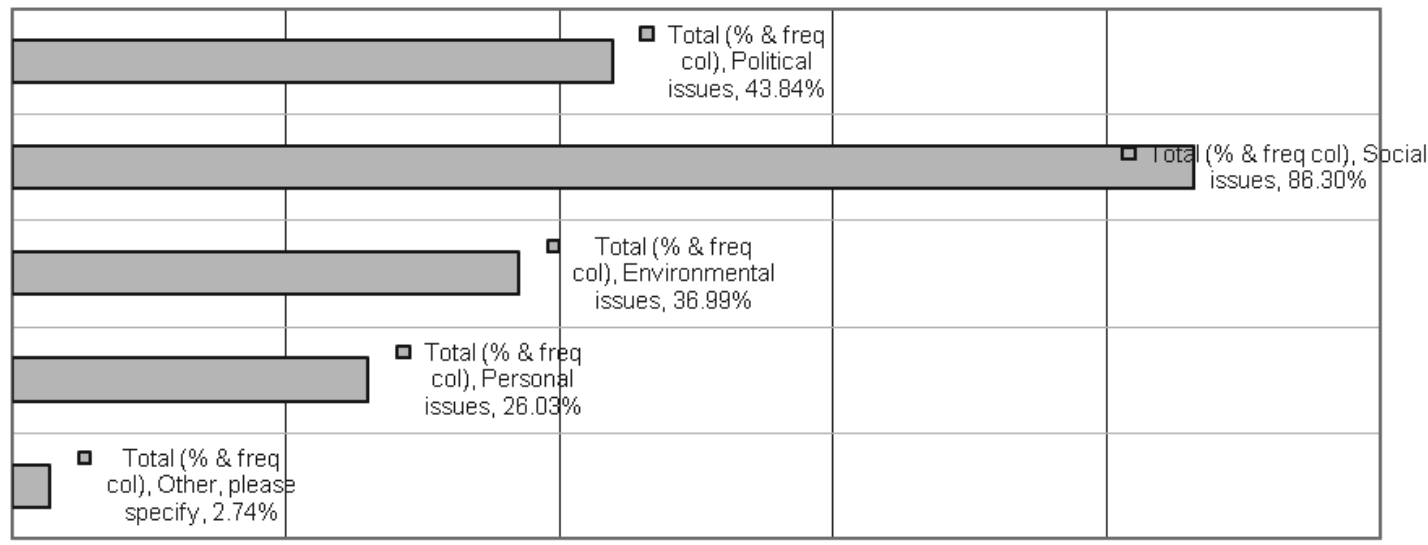

\section{The GS Road incident}

$57.53 \%$ of all the participants expressed their views in social media regarding the GS road Incident which took place on $9^{\text {th }}$ July 2012, in which a girl from Guwahati was molested by a group of men in busy GS Road, whereas $42.47 \%$ did not express anything regarding the incident in social media. 
Figure (5). Participation of the respondents in expressing their views in social media on the GS road incident which took place on $9^{\text {th }}$ July, 2012.

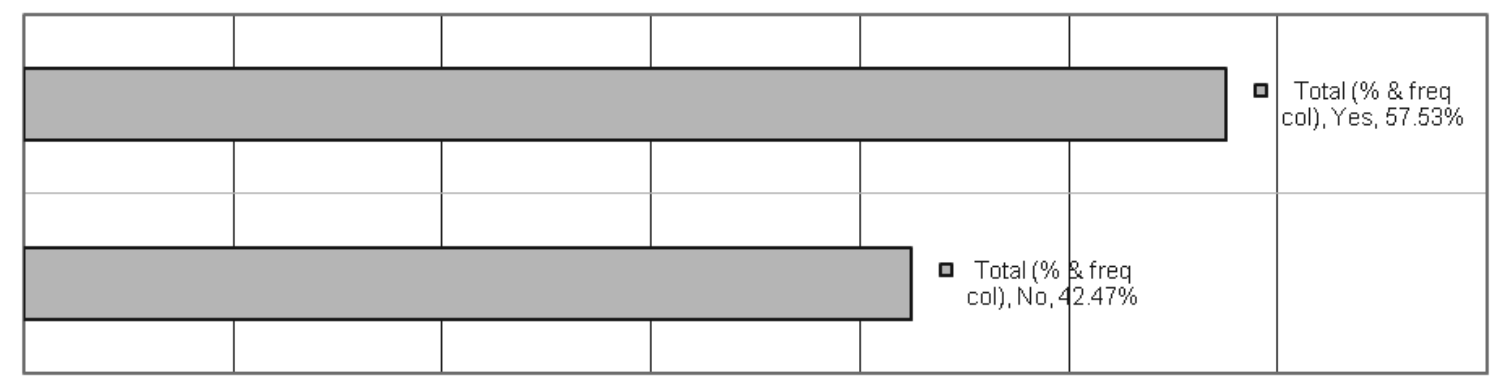

\section{Role of Social media in the GS road incident}

$73.97 \%$ of all the participants expressed their views regarding the Guwahati GS road incident in Facebook, 2.74\% in Twitter, 5.48\% in other social media sites, whereas $17.81 \%$ did not expressed their views in social media platform.

Figure (6). Platform used by the respondents in social media to express views on the GS road incident.

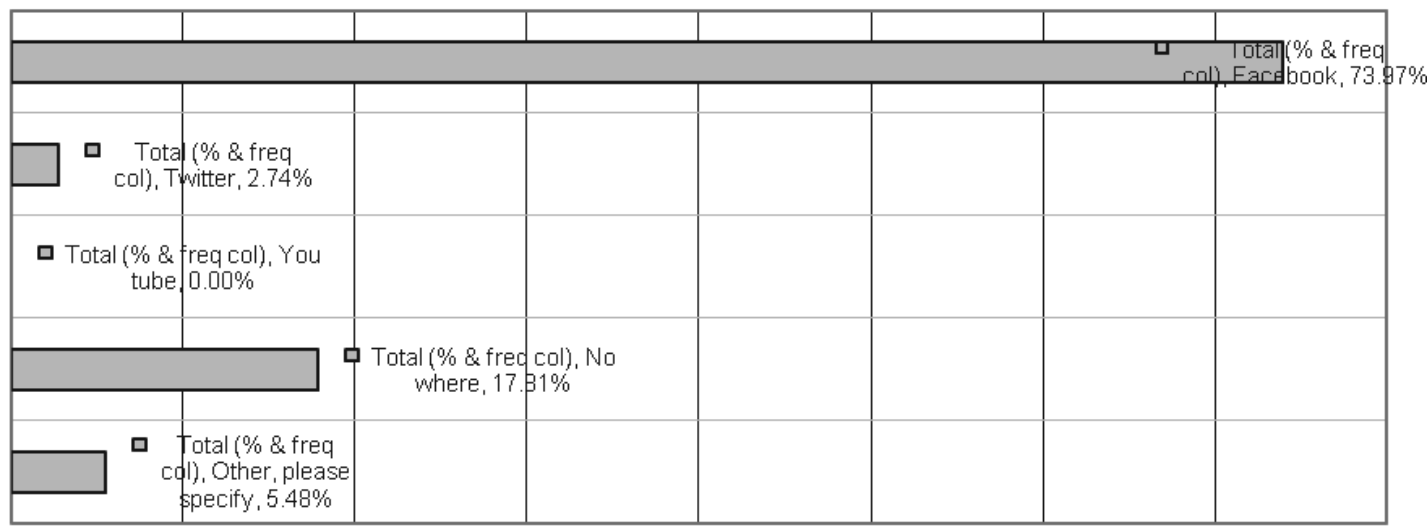

\section{Social media and activism}

$42.47 \%$ of the total participants strongly agree that Social media is an effective platform for staging

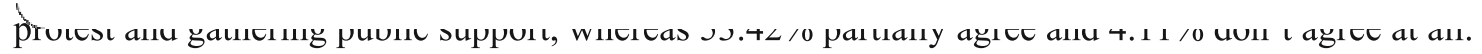


Figure (7). Perception of the respondents on the view that, Social media is an effective platform for staging protest and gathering public support.

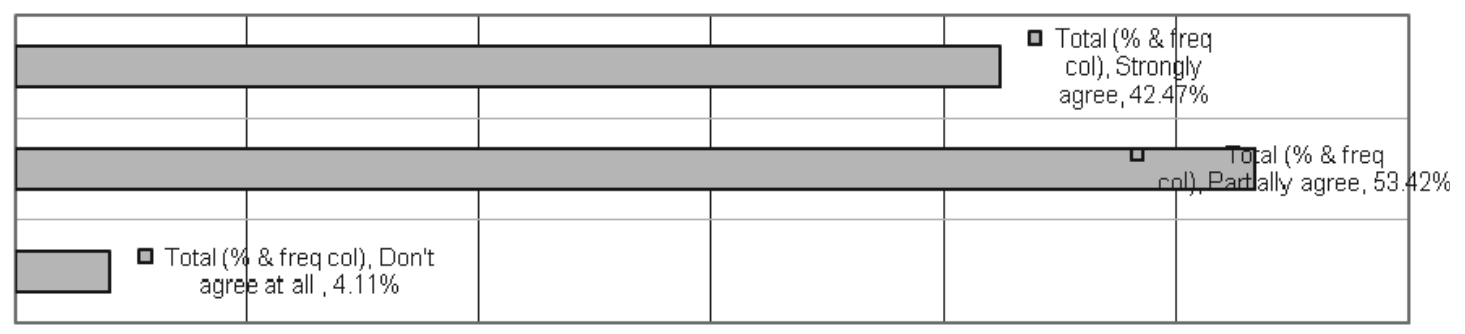

\section{Impact of cyber activism in real world}

$39.99 \%$ of the total participants strongly agree that protests in social media have also resulted in effective consequences in the real world and $58.90 \%$ partially agree, whereas $5.48 \%$ don't agree the fact at all.

Figure (8). Perception of the respondents on the effectiveness of cyber activism in real world.

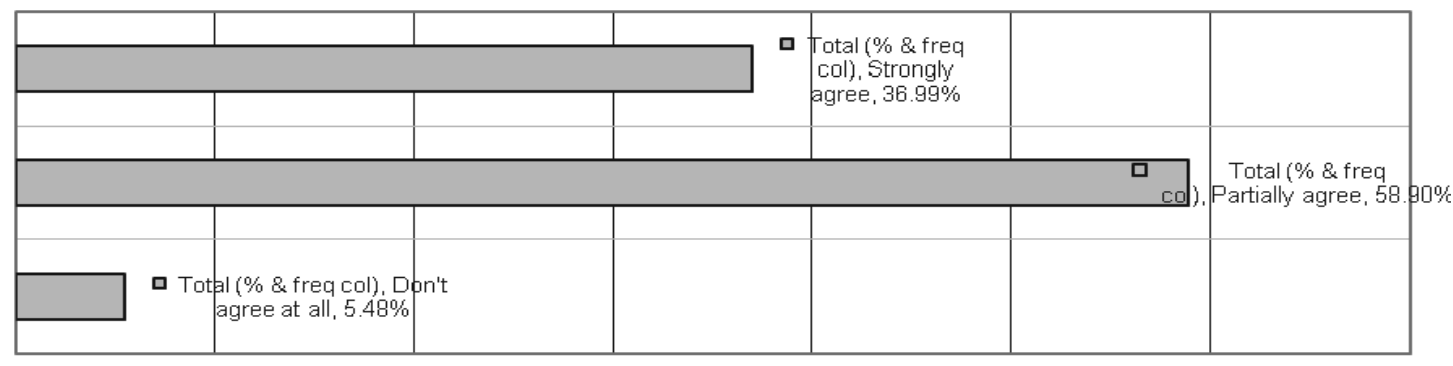

\section{The popular social media for cyber activism}

$90.41 \%$ of the total participants stage protests on issues rather than personal issues in Facebook, $1.37 \%$ in Twitter and $5.48 \%$ in blogs, whereas $2.74 \%$ stage protest in other social media sites.

Figure (9). Perception of the respondents on the use of popular social media platform for cyber activism.

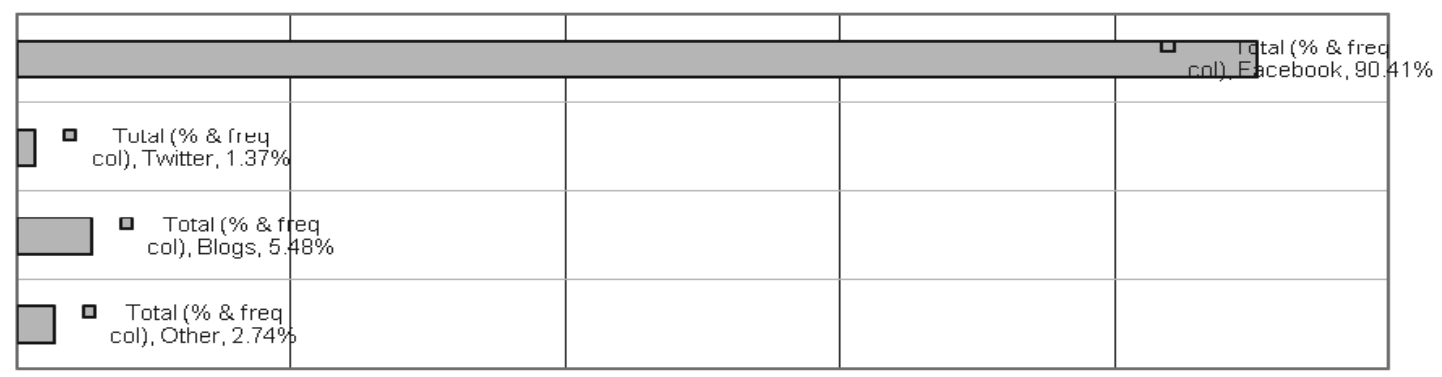




\section{Rising issue in social media in Assam}

$45.21 \%$ of the total participants believe that illegal Bangladeshi immigration is a growing issue in Social Media in Assam, 20.55\% believes that insecurity of women is a growing issue in Social media in Assam, $31.51 \%$ believes it is corruption whereas $2.74 \%$ believes there are other issues.

Figure (10). Perception of the respondents regarding the rising issues in the social media of Assam.

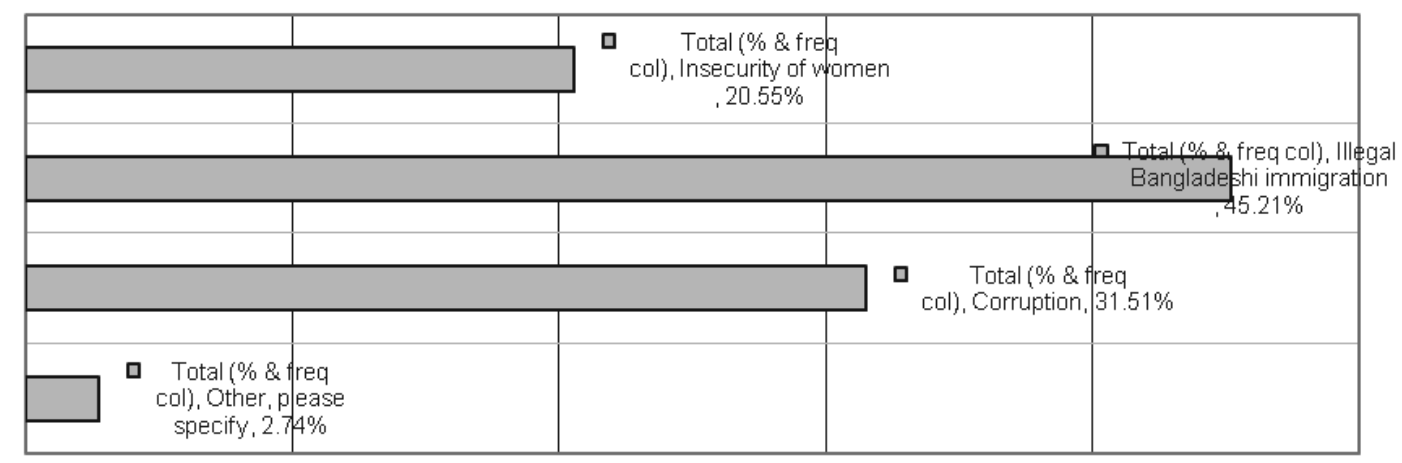

\section{Participation in the real world}

$78.08 \%$ of the total participants agreed to participate in the protests in real world which are organized, publicized in Social Media, whereas $21.92 \%$ did not agree.

Figure (11). Perception of the respondents regarding their participation in the real world protests that are organized and publicized in cyber world.

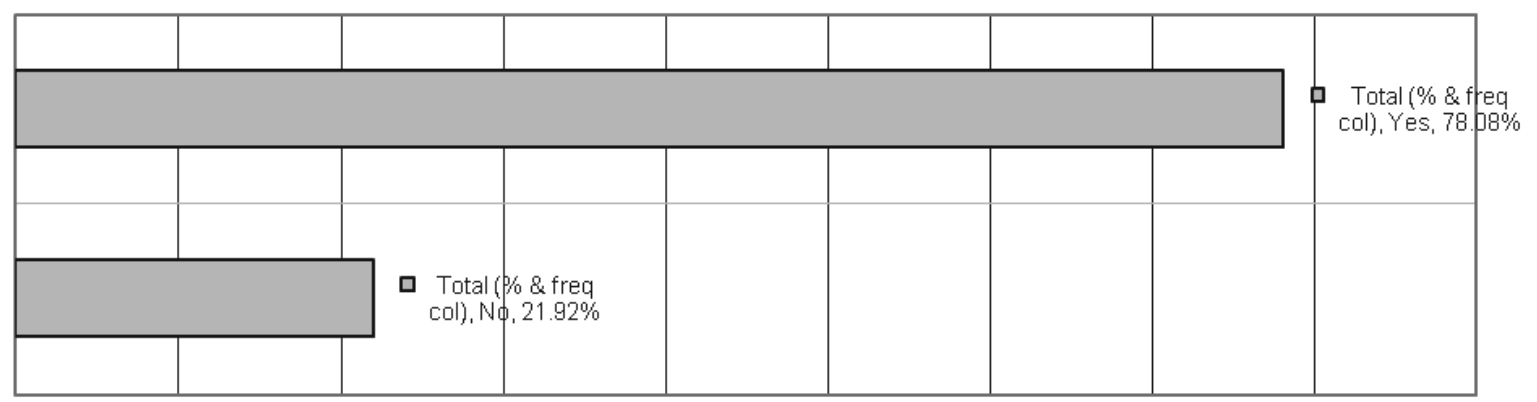

\section{CONCLUSION}

The state of art of Information and Communication Technology has enabled a transformation in the approach of activists and activisms. Research is beginning to explore how activist groups across the world are using social media to facilitate public engagement and collective action. Internet has the potentiality to increase the speed, reach and effectiveness of activist-related communication as well as mobilization efforts, and as a result it has a positive impact on activism in general. In these protests, the social media tools provided a common platform for the people of Assam, especially the youths to raise concerns about issues pertaining to their interest in the cyber 
world and perhaps as a result of these cyber activities, protest demonstrations and huge rallies were also carried out in the physical world. The issues of illegal immigration of the people from Bangladesh is most popularly hoisted and discussed among the various groups and communities from Assam in the social media platform.

In the series of these protests, the participation of the youth was particularly influenced by the Social Media, which was used to publicize, organize and create awareness among the people, particularly among the youths of Assam. The period can be therefore regarded as the beginning of cyber activism in Assam, since such protests were not seen in previous times where street rallies and protest demonstrations perhaps gained its momentum through online civic activities.

The urban and semi urban youths mainly participated in these protests; since the use and access to internet is popular and pervasive among youths in these areas of Assam. Facebook being the most popular among all the social media between the youths have enabled the youth to share a common platform, where users communicate, exchange and connect with each other. It is also seen that the users tend to publicize and organize events online and offline through the medium which indeed have revolutionized the modus operandi of collective activities by increasing the effectiveness and speed of the intended communication. The impact of social media on youth cyber activism in Assam is quite prominent, pertaining to the increasing number of online/offline participation of the youth in such activities.
MANOJ DEORI, Lecturer; SUNIL K. BEHERA, Professor, Department of Journalism and Mass Communication, Berhampur Univeristy, India.

\section{REFERENCES}

Andrews, D., Nonnecke, B. \& Preece, J. (2003). Electronic survey methodology: A case study in reaching hard to involveinternet users. International Journal of HumanComputer Interaction, 16(2), 185-210.

Axford, B. (2011). Talk about a revolution: Social media and the MENA uprisings. Globalizations, 8(5), 681-686.

Boyed, D \& Ellision, N. (2007). Social network sites: Definition, history, and scholarship. Journal of Computer Mediated Communication, 13(1), 210-230.

Boyed, D. (2007). Why youth (heart) social network sites: The role of networked publics in teenage social life. In D. Buckinghm (Ed). MacArthur Foundation Series on Digital Learning - Youth, Identity, and Digital Media Volume (ed. p. 119-142). Cambridge, MA: MIT Press.

Kahn, R. \& Kellner, D. (2004). New media and internet activism: From the battle of seattle' to blogging. New Media \& Society, 6(1), 87-95.

Krejcie, R. V. \& Morgan, D. W. (1970). Determining sample sizes for research activities. Educational and Psychological Measurement, 30, 607-610.

Nayar, P. (2008). New Media, digitextuality and public Space: Reading cyber-mohalla. Postcolonial Text, 4(1), 58-63.

Schwittlay, A. (2011). New media practices in India: Bridging past and future, markets and development. International Journal of Communication, 5, 349-379.

Wallis, C. (2011). New media practices in China: Youth Patterns, Processes, and Politics. International Journal of Communication, 5, 406-436. 